Revue des patrimoines

Jean-Pierre Cometti. Conserver / Restaurer. L'œuvre d'art à l'époque de sa préservation technique. Collection NRF Essais, Gallimard, 2016.

\title{
Léonie Hénaut
}

\section{OpenEdition}

Journals

Édition électronique

URL : http://journals.openedition.org/insitu/13752

DOI : 10.4000/insitu. 13752

ISSN : 1630-7305

Éditeur

Ministère de la Culture

Référence électronique

Léonie Hénaut, « Jean-Pierre Cometti. Conserver / Restaurer. L'œuvre d'art à l'époque de sa préservation technique. Collection NRF Essais, Gallimard, 2016. », In Situ [En ligne], 30 | 2016, mis en ligne le 30 septembre 2016, consulté le 24 septembre 2020. URL : http://journals.openedition.org/insitu/13752 DOl : https://doi.org/10.4000/insitu.13752

Ce document a été généré automatiquement le 24 septembre 2020.

\section{(c) (i) $(9)$}

In Situ Revues des patrimoines est mis à disposition selon les termes de la licence Creative Commons Attribution - Pas d'Utilisation Commerciale - Pas de Modification 4.0 International. 


\section{Jean-Pierre Cometti. Conserver / Restaurer. L'œuvre d'art à l'époque de sa préservation technique. Collection NRF Essais, Gallimard, 2016.}

Léonie Hénaut

Compte rendu de lecture. A VENIR 